\title{
4. 産業用無人ヘリコプタ画像を利用した自動可変施肥システム
}

米山晶* ・清野 伸孝* ・横堀 潤*

\section{1.はじめに}

北海道十勝管内の農家一戸当たりの耕地面積は 1985 年に23.5ha であったが, 2005年には 38.1 ha (農業セン サス2005）と経営の大規模化が進んでいる。従来は戋 場面積が小さいため戋場単位に異なる管理を行うこと は可能であった。しかし，近年農地の利用集積や戋場 の大区画化にともない圑場内, 圃場間の土壤肥沃度の ばらつきが増大している（糸川，2007）。

この対策として, 娄場内の作物生育や土壤のばらつ きを理解し，作物生産に関わる多数の要因間の関係性 を科学的に解明しながら意思決定を支援する営農戦略 体系である「精密農業」が近年注目されている (National Research Council, 1997)。

精密農業はミネソタ大学の土壤学者ら（Pierre C.R et al，1996）が提唱したもので,「作物・土壤情報セン シング」,「診断と意思決定」,「可変投入」の 3 つのカ テゴリから構成される。その中でも「作物・土壤情報 センシング」は, 固場内の作物生育や土壤のばらつき を正確に把握することを目的としている(渋澤, 1999)。

また，固場内の作物生育や土壤のばらつきを把握す るためのセンシング技術として，産業用無人へリコプ 夕をべースとしたセンシングシステムが提案されてい る(野口，2003）。

近年, 営農現場では肥料価格高騰の問題に直面して おり, 適正施肥による肥料コストの削減が急務となっ ている。固場内の作物生育や品質の均一化, 適正施肥 による肥料コスト削減を図るためには, 土壤肥沃度に 基づいた適正な施肥作業を行うことが重要であり，そ れを解決する手段の一つとして「可変施肥技術」の導 大が有効と考えられる。

(怢ズコーシャでは，2007年から経済産業省の新連携 事業により，ヤンマーヘリサービス怢，(侏)サークル鉄 工, (有)クノファーム, 有)ビズ総合研究所と共に IT 農 業支援システムの構築に取り組んでいる。

*株式会社ズコーシャ 総合科学研究所

「写真測量とリモートセンシング」VOL. 48, NO. 5， 2009
本稿では，構築中のシステムの中でも，実用化にこ ぎつけた産業用無人へリコプタ画像を利用した自動可 変施肥システムの紹介をする。

\section{2. 自動可変施肥システムの概要}

自動可変施肥システムは, (1)産業用無人へリコプタ によるリモートセンシング, (2)リモートセンシング画 像の解析とマップ作成, (3)自動可変施肥, の 3 つのプ ロセスに大きく分けることができる。

\section{1 産業用無人ヘリコプタによるリモートセンシン グ}

産業用無人へリコプタをべースとしたセンシングシ ステムは, 北海道大学農学部ビークルロボティクス研 究室が開発したものである。

産業用無人へリコプタに, 画像取得のための光学セ ンサや, 環境光量センサ, それらセンサからのデータ を保存するノートパソコン, GPS 機器などを搭載して センシングを行う。

\section{2 リートセンシング画像の解析とマップ作成}

リモートセンシングによって取得された画像の解析 を行い，可変施肥用のマップを作成する。

\section{3 自動可変施肥}

作成された可変施肥用のマップを使用して, 自動可 変施肥を行う。

\section{3. センシング機器概要}

\section{1 産業用無人ヘリコプタ（ヤンマー(陎製 $\mathrm{AYH}-3$ )}

リモートセンシングに利用する産業用無人へリコプ 夕は，ヤンマー(侏製 $\mathrm{AYH}^{-} 3$ (写真 1 ) で, 空撮用に 開発されているものである。このへリコプタは, 無線 操縦機によって遠隔操作ができる全長約 $3.6 \mathrm{~m}$ のラジ コンタイプのヘリコプタである。 


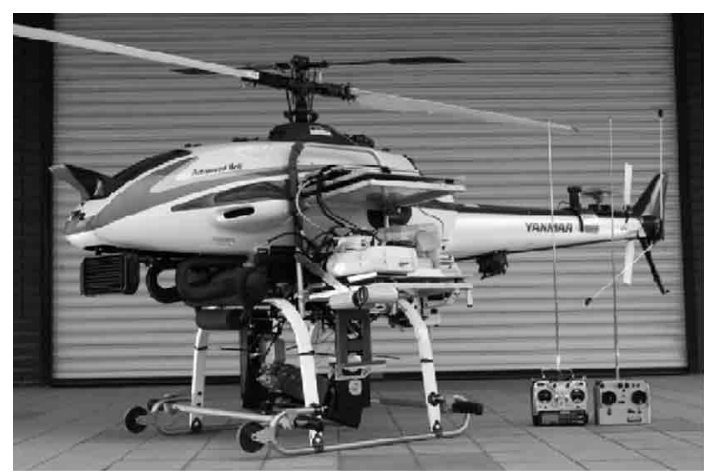

写真 1 産業用無人ヘリコプタ AYH-3

\section{2 イメージングセンサ}

画像を取得するセンサには, Duncan Tech 社製のマ ルチスペクトルイメージングセンサ (以下, MSIS) で ある，MS4100（写真 2) を採用した。

これをピッチ方向のみ遠隔制御できる雲台に取り付 けた。MSIS は 3 チャンネルの光学バンドパスフィル 夕を内蔵しており，緑 (Green, 中心波長 $540 \mathrm{~nm})$, 赤 (Red，中心波長660nm)，近赤外（Near Infrared： $\mathrm{NIR}$, 中心波長 $810 \mathrm{~nm}$ ) の波長領域の反射光強度が検出 できる。各バンドの半值幅は, Green が65nm, Red が 57nm, NIR が155nm である。また, MSIS に装着する レンズには, 焦点距離 $14 \mathrm{~mm}$, 対角線画角 $37.5^{\circ}$ もの を採用した。画像解像度は $640 \times 360$ ピクセルであり, 取得された画像デー夕は, NTSC 方式にアナログ転送 され，ビデオキャプチャカードによって $\mathrm{A} / \mathrm{D}$ 変換さ れたデー夕を各波長それぞれ256階調で,機体横に装備 したノートパソコンに取り込むことができる。

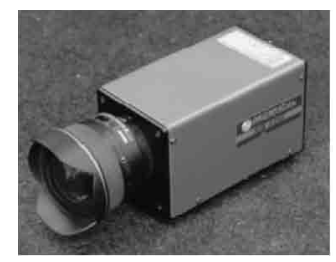

写真 2 MSIS MS4100

\section{3 環境光量センサ}

屋外環境下でのセンシングは，様及な外乱の影響を 受ける。その中でも，太陽光量の変動による影響は無 視できない。光源の強さである半球放射照度を測定す るために, ヘリコプタのテールブームに SKYE 社製環 境光量 (Ambient Illumination : AI) センサ SKR-
$1850 \mathrm{~A}$ (方位角特性 1\%，コサインエラー $3 \%\left(<80^{\circ}\right)$, 直線性 $<0.2 \%$ )（写真 3 )を搭載している。この $\mathrm{AI}$ 七 ンサの中心波長は, 緑 $(550 \mathrm{~nm})$, 赤 $(670 \mathrm{~nm})$, 近赤外 $(900 \mathrm{~nm})$, 各バンドの半值幅環境光量センサからの光 量データはバンド毎にアナログ出力され，16ビットの $\mathrm{A} / \mathrm{D}$ 変換器を介して,ノートパソコンに取り込まれ る。

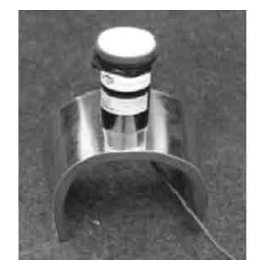

写真 3 Al センサ SKR-1850A

\subsection{GPS 機器}

ヘリコプタやセンシング対象物の位置を正確にかつ 迅速に把握するためには，GPS を利用してへリコプタ の位置を測定する必要がある。GPS 機器としてRTK -GPS (TOPCON GB1000)（写真 4 ）を搭載している。 GB1000は, スタティック観測や RTK 観測が可能な 機種で，内蔵のバッテリにより動作する。

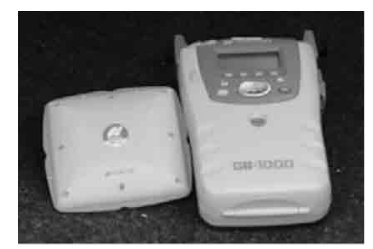

写真 4 RTK-GPS GB1000

\section{4.リモートセンシング}

\section{1 固場センシング}

各種機材を搭載したへリコプタは，調查対象の围場 周辺から安全を確認の上離陸させ, 畨場の表層土のセ ンシングを行う。離陸したへリコプタは地上のオぺ レータにより操縦される。MSIS の画像は, 画像伝送装 置により地上にあるモニタへ送信されており，その画 像を参考にへリコプタの位置, 向き, 雲台の傾きを遠 隔操作する。へリコプ夕に搭載されているノートパソ コンでは,数秒拉きに自動的に画像が保存されている。

ヘリコプタは対地高度 $40 \sim 50 \mathrm{~m}$ ほどの低空を飛行 するため, 人工衛星のように雲の影響を受けることが なく, 晴天の時だけでなく, 是天の時にも撮影を行う 
ことができる。また，後述する俯角撮影方式において は, 対地高度や俯角の角度, 围場条件などに左右され るが，1 日あたり約 50 ha の計測を行うことができる。 さらに画像は数 $\mathrm{cm} \sim 4 \mathrm{~m}$ の解像度で取得することが できる。

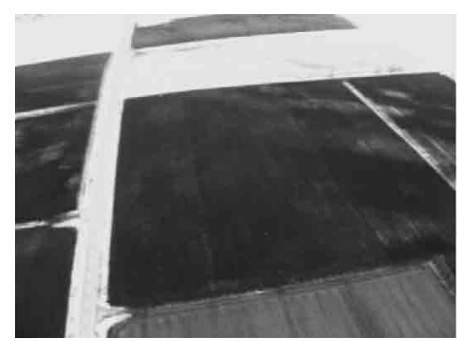

写真 5 俯角撮影方式の画像例

\section{2 俯角撮影の概要}

撮影方法の概略を図 1 に示す。一度により広範囲の 撮影を可能とするために，俯角をつけて撮影を行って いる。MSISの俯角はへリコプタに搭載された雲台に より制御し，カメラ光軸が垂直下向きの時に俯角を 0 。 として, ヘリコプタ後方向の回転を正としている。

俯角撮影方式は，(1)撮影画像枚数および後述する幾 何補正にかかる労力が軽減されるとともに，(2)戋場土 壤図としての十分な解像度及び鉛直下方撮影画像と同 等の推定精度が確保される（丹羽ら，2008）。

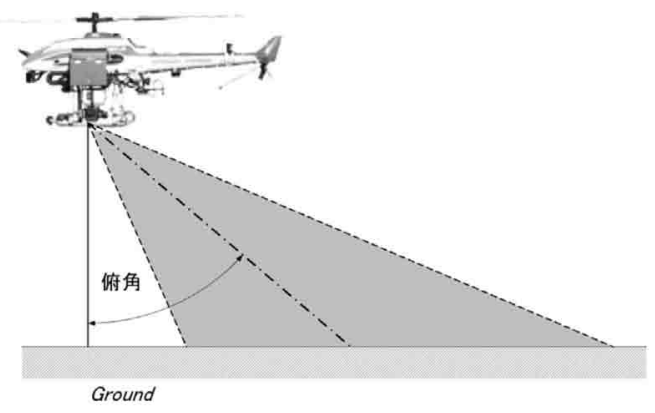

図 1 俯角撮影方式

\section{5 . 画像解析}

\section{1 俯角撮影画像の幾何補正}

一般に，画像の幾何補正は元画像に含まれる歪みを 取り除くことを目的としている。幾何補正にはアフィ ン変換，射影変換，へルマート変換などが用いられて おり, 歪みの種類に応じた変換式を適用する必要があ る。この中でも, 射影変換は平面および 3 次元に配置
されている物体をカメラ等で撮影した際に，画像化さ れたデー夕に生じるカメラ傾斜歪みを補正する上で有 効である(宮本ら，2006)。そこで俯角撮影画像の補正 には, 幾何補正法の中から， 2 次元射影変換を採用し た。また，ピクセルの輝度值を保持するために，内挿 法は最近隣内捙法（Nearest Neighbor）を使用する。 2 次元射影変換後の画像は, 全てのピクセルが地理的 絶対座標を持つ。

\section{2 画像からの反射率取得}

画像の各ピクセルにある輝度值データから, 反射率 への変換を行う。反射率 Ref [\%] は MSIS の制御項 目である露光時間，CCD ゲインを考慮し，式(1)のよう に算出する。

$\operatorname{Ref}_{i}=\frac{C_{0} G L_{i}+C_{1}}{\left(A I+C_{2}\right)\left(\exp +C_{3}\right)\left(e^{C_{4} \text { gain }}+C_{5}\right)}$

Ref : 反射率 [\%]

$G L:$ 輝度 $[$ 一 ] (デジタルナンバ)

$A I$ : 環境光量 $\left[\mu \mathrm{molm}^{-2} \mathrm{~S}^{-1}\right]$

exp : 露光時間 $[\mathrm{ms}]$

gain : $\mathrm{CCD}$ ゲイン $[\mathrm{dB}]$

$C_{0} \sim C_{5}$ : 定数

なお，定数 $C_{0} \sim C_{5}$ の決定には，石井ら (2006)の方 法に準じ作物葉部の光反射率に近い葉色カラースケー ル（富士平工業株式会社）を朝から夕方まで撮影して 取得した值を採用した。

\section{3 反射率からの熱水抽出性窒素の推定}

これまでの研究成果から, 土壌情報として土鎄腐植 含量 (畠中ら, 1989, 丹羽ら, 2004) が, 光学センサ を利用したリモートセンシングから精度良く推定でき ることが示されている。また, 火山灰土地帯では, 土 㙵腐植含量を間接評価することにより, 熱水抽出性窒 素（西宗，1994）を把握できることが示されている。

熱水抽出性窒素は, 北海道で窒素肥沃度の指標とし て活用されており，テンサイ，バレイショ，小麦等の 普通畑作物においては熱水抽出性窒素べースの窒素施 肥管理方法が確立されている（北海道農政部，2002）。

画像から得られる反射率と現地土壤サンプリング地 点の熱水抽出性窒素の分析值との比較を行った結果, 画像から得られる近赤外の反射率と, 熱水抽出性窒素 の分析值の間には, 高い負の相関関係が得られ(図 2) (丹羽ら，2008)，火山灰土地帯においては反射率から 
直接，高い推定精度 $\left(\mathrm{R}^{2}=0.85\right.$ 程度）で，高解像度（数 $\mathrm{cm} \sim 4 \mathrm{~m})$ の熱水抽出性窒素マップの作成が可能であ ることを確認している（図３）（丹羽ら，2008）。

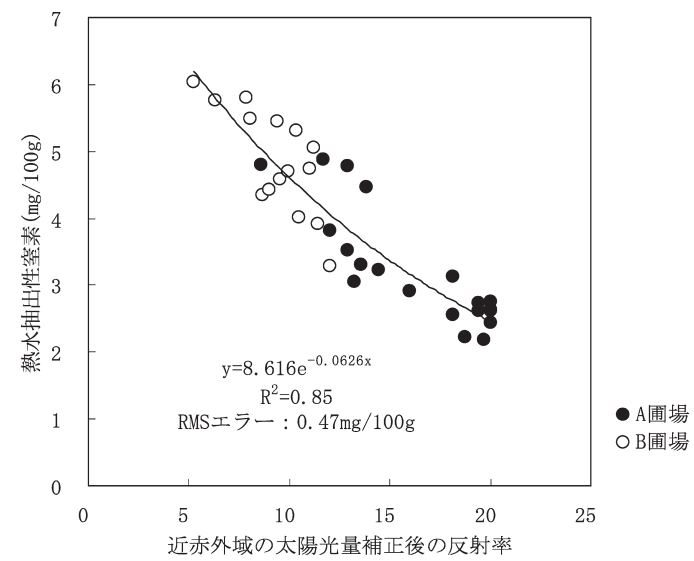

図2ヘリコプタ画像から得られた近赤外域の反射率と熱 水抽出性窒素の関係例

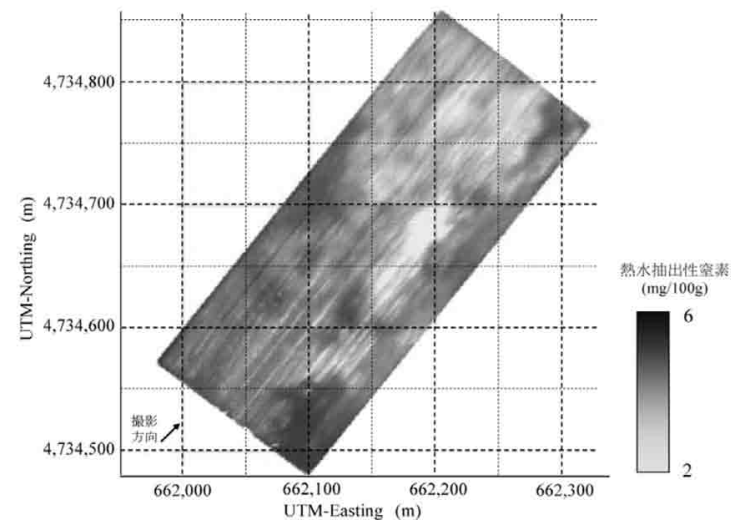

図3ヘリコプタ画像から作成した熱水抽出性窒素地図の 作成例

\section{4 窒素可変施肥マップの作成}

図 4 に窒素可変施肥マップの作成イメージを示す。

これまでの手順を踏み，作成された熱水抽出性窒素 マップから, 各地点の窒素投入量に変換した窒素可変 施肥マップを作成する。

熱水抽出性窒素マップでは, 土壤由来の窒素放出量 を地点毎に読み取ることができるので，窒素可変施肥 マップを作成する際は，各地点に打ける熱水抽出性窒 素の值からそれぞれを窒素施用量に変換してマップ化 することを基本としている。

このマップは, 自動可変施肥機の制御に使用するこ とができる。
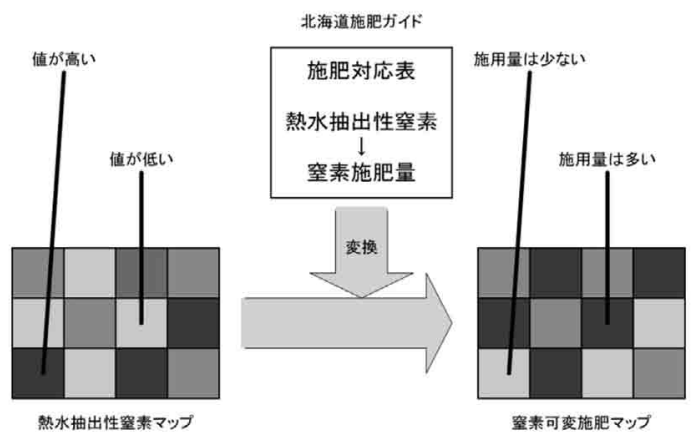

図 4 窒素可変施肥マップ作成のイメージ

\section{6. 自動可变施肥}

\section{1 自動可变施肥機}

図 5 に自動可変施肥機の概略を示寸。

サークル機工怢が開発した自動可変施肥機は, 従来 の施肥機に加えて, GPS, 可変施肥用パソコンと施肥 量制御用マイコンから構成される。

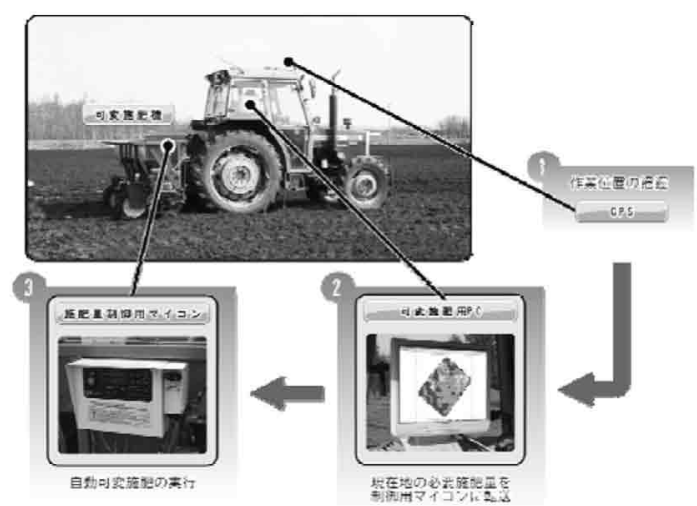

図 5 自動可変施肥機の概略

可変施肥用パソコンには,「予めパソコンにインプッ トした窒素可変施肥マップの情報と GPS から送信さ れる作業位置を照合する機能」,「現在地の必要施肥量 を制御用マイコンヘリアルタイム送信する機能」を有 するソフトウエアがインストールされており, 可変施 肥は(1) GPSによる現在位置の把握，(2)可変施肥用パ ソコンによる現在地の必要施肥量の把握とその施肥量 のマイコンへの送信, (3)マイコンによる施肥量の調整, の 3 段階を経て実施される。

オペレー夕は, 投入量の手動による切り替えが一切 不要で，これまでどおりトラク夕を走行させるだけで 良い。 


\section{2 自動可変施肥の効果}

2006年から2008年にかけて，連携企業である(有)テク ノ・ファームのテンサイ作付戋場で， 1 ～ 3 ha の規模 を持つ窒素可変施肥区と窒素慣行施肥区を設け, 窒素 可変施肥の有効性を検討した。

各調查年とも窒素可変施肥区では, 慣行施肥区に比 べて25～50\%もの窒素施肥量を削減したにもかかわら ず，窒素慣行施肥区と同程度の糖量を維持することが できた。また，2006年，2007年では，窒素可変施肥区 の糖量の標準偏差が, 窒素慣行施肥区よりも小さく, 熱水抽出性窒素マップに基づく窒素可変施肥は, 窒素 施肥量の削減と共に戋場内の作物生育と品質の均一化 に貢献すると考えられる（星山ら，2009）。

\section{7.まとめ}

産業用無人へリコプタを利用したリモートセンシン グは，(1)高精度のセンシングを行うことができる。(2) 曇天でも撮影が可能なため, センシングの機会が増大 する。などの利点がある。

(怢)゙コーシャでは, 産業用無人へリコプタによるリ モートセンシング技術の他の用途の使用例として, こ の技術を小麦の収穫順マップにも適用し，悪天候など の理由で人工衛星画像が撮影できない場合のバック アップとして活用する方法も検討している。

熱水抽出性窒素マップを作成し, 窒素可変施肥マッ プに変換することにより，そのマップを利用した自動 可変施肥が可能となることにより, 自動可変施肥には, 窒素施肥量の削減をしながらも, 生産性は維持される 利点がある。

これらの技術は, 生産コストの削減や環境負荷の軽 減等, 営農現場に大きく貢献することを期待している。

\section{参考文献}

石井一暢, 杉浦 綾, 深川知久, 野口 伸, 柴田洋一, 2006 ：マルチスペクトルイメージングセンサを用い た生育診断システムの構築 (第 1 報), 農業機械学会 誌, 68(2), pp.33-41.

糸川信弘，2007：畑作における精密農業技術の適用条
件扔よび展望, 農業機械学会誌, 69(6), pp. 4-7. 渋澤 栄, 1999 : 米国プレシジョンアグリカルチャへ の訪問, 農業機械学会誌, 61(1), pp. 7-12.

西宗 昭, 1994 : 農業生産における土壤管理の将来一 北海道十勝地域をモデルに一, 北海道農試研究資料, 50, pp. $97-115$.

丹羽勝久, 清野伸孝, 明石憲宗, 菊地晃二, 2004 : 北 海道十勝管内の火山性土地帯における大縮尺土壤図 の作成, 日本土壌肥料学雑誌, $75, \mathrm{pp} .69-78$.

丹羽勝久, 横堀 潤, 清野伸孝, 星山賢一, 2008：俯 角を付けたマルチスペクトルイメージングセンサを 利用した有機物含量および熱水抽出性窒素地困の作 成, 農業機械学会北海道支部会報, 48, pp.57-61. 農林水産省北海道農政事務所带広統計・情報セン ター：農業センサス 2005 .

野口 伸, 2003 ：産業用無人へリコプタを適用した戋 場環境のモニタリング, 農業機械学会誌, 65(4), pp. 13-17.

畠中哲哉, 塩崎尚朗, 福原道一, 宮地直道, 斉藤元也, 1989 ：ランドサット TM データによる畑地表土の 腐植含量評価, 日本土壌肥料学雑誌, $60, \mathrm{pp} .426-431$. 星山賢一, 榎本吉典, 丹羽勝久, 2009 ：リモートセン シング技術を活用した自動可変施肥システム, 農業 土木北海道, 31, pp.11-15.

北海道農政部，2002：北海道施肥ガイド.

(http://www.agri.pref.hokkaido.jp/nouseibu/sehi guide/)

宮本 徽, 北原 格, 亀田能成, 大田友一, 2006：Floating Virtual Mirrors：浮動式仮想鏡による車両背後 領域の可視化, 電子情報通信学会技術研究報告, MVE2006-45, pp.13-18.

National Research Council, 1997 Precision agriculture in the $21^{\text {st }}$ century. National Academy Press, pp.149.

Pierre C.R., Rust R.H., and Larson W.E., Ed. 1996, Precision Agriculture Proceedings of the $3^{\text {rd }}$ International Conference, June23-26, Minneapolis, Miusa, ASA/CSSA/SSSA, 1-1222. 